\title{
A CONCRETUDE DA ABSTRAÇÃO
}

\author{
JAPPE, Anselm \\ As aventuras da mercadoria: para uma nova crítica do valor \\ Lisboa: Antígona, 2006
}

\section{POR}

\section{Ricardo Pagliuso Regatieri ${ }^{1}$}

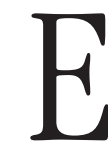

m As aventuras da mercadoria: para uma nova crítica do valor, Anselm Jappe privilegia a crítica categorial que se pode encontrar na teoria do Marx maduro. Ao passo em que realiza uma apresentação dessa teoria, Jappe segue seus rastros em desenvolvimentos ulteriores (tratando, em especial, de autores e discussões da Alemanha das últimas duas décadas) e propõe sua própria leitura, pautada pelas condições históricas do presente. Pela ótica dessa leitura atualizada, abordam-se tanto algumas variantes do movimento antiglobalização como o marxismo tradicional que animou a atuação política da esquerda.

Jappe, nascido em 1962 em Bonn, na Alemanha, atualmente vive entre a França e a Itália. Foi colaborador, de 1993 a 2003, da antiga revista Krisis, de Nuremberg, cujo membro mais conhecido por aqui é Robert Kurz. De Anselm Jappe, foi publicado no Brasil Guy Debord, pela editora Vozes em 1999. As aventuras da mercadoria foi lançado na França em 2003 e traduzido para o português pela Antígona, de Lisboa, em 2006. Seu tema já aparecera no doutorado de Jappe ( $L a$ critique du fétichisme de la marchandise chez Marx et ses développements chez Adorno et Lukács) na École des Hautes Études en Sciences Sociales. E seu

\footnotetext{
${ }^{1}$ Mestrando do Programa de Pós-graduação em Sociologia da Faculdade de Filosofia, Letras e Ciências Humanas da Universidade de São Paulo. End. eletrônico: ricardopagliuso@hotmail.com
} 
título não deixa esquecer As aventuras da dialética (1955), de Maurice MerleauPonty. A obra procura trazer à luz, para o público francês, desdobramentos a partir de Marx que se encontram dispersos em publicações e pesquisas que Jappe expõe de forma clara e por meio de um bem-sucedido esforço de síntese. Aparecem, por exemplo, pela primeira vez coligidos num só texto, os principais desenvolvimentos teóricos do antigo grupo Krisis.

As aventuras da mercadoria se inicia (o primeiro capítulo é intitulado "Será o mundo uma mercadoria?") e se encerra (com o capítulo "Sobre alguns falsos amigos") com a crítica das organizações, movimentos e publicações, hoje em voga, que combatem o "neoliberalismo". Para Jappe, a oposição à desregulamentação estatal, à especulação financeira ou às multinacionais fica a meio caminho daquilo que ele identifica como o núcleo de uma crítica conseqüente do capitalismo, pois atinge seus fundamentos: a crítica categorial propiciada pela crítica da economia política de Marx, encontrada principalmente nos Grundrisse, em Para a crítica da economia política e em 0 capital. Mercadoria, valor, dinheiro e fetichismo são categorias basais do modo de produção capitalista e de sua respectiva socialização. A sociabilidade capitalista se efetua no âmbito das amarras invisíveis da forma social total do valor, que tem por princípio a abstração dos conteúdos concretos. A crítica social não pode avançar muito quando se detém somente em aspectos parciais.

Com a decomposição do mundo tradicional, a aurora do mundo burguês e a evolução do capitalismo, constituem-se e consolidam-se aquelas esferas que promovem a separação da unidade orgânica anterior. Jappe põe nesses termos essa passagem: "A partir do momento em que o valor se impõe enquanto forma da totalidade social, implica o nascimento de subsistemas diferenciados. 0 valor, com a sua pulsão impessoal para a ampliação tautológica, não é uma categoria puramente 'económica', à qual se pudesse opor a 'política' como se esta fosse a esfera do livre arbítrio, da discussão e da decisão em comum” (p. 157). Forma social total significa, para Jappe, que o "valor não se limita a ser uma forma de produção; é também uma forma de consciência" (p. 159). E o é "não apenas no sentido em que cada modo de produção produz ao mesmo tempo formas de consciência correspondentes", pois o "valor, à semelhança de outras formas históricas de fetichismo, é algo mais: é uma forma a priori, no sentido de Kant" (p. 159). A própria subjetividade é pré-formada por esse a priori, como "uma retícula de que o indivíduo não tem consciência" (p. 170). Assim, "tudo o que os sujeitos do valor possam pensar, imaginar, querer ou fazer, oferece-se já sob 
a forma de mercadoria, de dinheiro, de poder do Estado, de direito" (p. 159160). Aqui é possível ver como Jappe expressa a idéia de Marx de que a sociedade capitalista e sua lógica cega constituem um sujeito automático.

0 acento posto na crítica do valor e do fetichismo, pilar da crítica categorial que trespassa todo o livro, corresponde, segundo Jappe, à tematização de uma parte da obra de Marx que em geral não esteve em primeiro plano. 0 marxismo tradicional, desde Engels, considerou que a parte central da teoria de Marx era a que dizia respeito à luta de classes. 0 trabalho foi ontologizado e a palavra de ordem era libertar o trabalho que estaria subsumido pelo capitalismo. Contrariamente a interpretações que enveredam por essas vias, Jappe propõe que se deve partir daquelas categorias da crítica da economia política - mercadoria, valor, fetichismo - com que Marx inicia O capital: "0 marxismo tradicional, sobretudo na sua qualidade de ideologia oficial das diferentes correntes do movimento operário, seguiu um caminho completamente diferente. Para 0 marxismo tradicional, a confrontação fundamental do capitalismo é o conflito entre trabalho e capital" (p. 93), porém este, "por importante que tenha sido historicamente, é um conflito no interior do capitalismo. Trabalho assalariado e capital não são mais do que dois estados de agregação da mesma substância: 0 trabalho abstracto coisificado em valor. São dois momentos sucessivos do processo de valorização, duas formas do valor" (p. 94). No que tange à ontologização do trabalho, deve-se considerar que nomear de "trabalho" atividades humanas tão diversas e incomensuráveis é desde logo um procedimento capitalista que, aos olhos de quaisquer outras sociedades que não a sociedade mercantil, se afiguraria como um procedimento totalmente absurdo e sem sentido. Não se trata de libertar uma essência boa aprisionada, mas de criticar a própria abstração "trabalho", que mais bem já é o trabalho abstrato capitalista. Jappe considera que o grande mérito de Marx foi mostrar que no capitalismo a dominação se processa por abstrações socialmente constituídas, mas que se emanciparam do controle humano. 0 método de Marx, diz Jappe, descreve "o traço específico da sociedade mercantil, na qual são categorias abstractas que constituem o prius, o momento primeiro, da vida social, enquanto os homens e os respectivos actos conscientes não são senão os executores dessas categorias" (p. 89).

Seja para ter um contato com Marx e o marxismo sob outros ângulos, seja para ver uma abordagem pouco usual dos movimentos antiglobalização, vale muito a pena ler As aventuras da mercadoria. 0 livro de Anselm Jappe logra reunir dissonância em relação ao pensamento estabelecido com clareza de exposição - 
essa segunda qualidade permite considerá-lo uma excelente introdução à temática da crítica do valor, não obstante ter caráter muito diferente do de um manual. Clareza que, contudo, de maneira alguma implica em simplificação teórica. Jappe coloca 0 valor como cerne da explicação da vida social moderna sem jamais perder de vista a totalidade abstratificada do sujeito automático capitalista, e por isso As aventuras da mercadoria não padece de economicismo, mas antes põe na ordem do dia uma perspectiva crítica que cabe retomar e desenvolver. 